\title{
FARMING IN THE TE KUITI DISTRICT
}

\author{
D. B. WRIGHT
}

Farm Advisory Officer,; Ministry of Agriculture and Fisheries, Te Kuiti

\section{Abstract}

Farming patterns of the Te Kuiti district. are described. Progress is reviewed, and comments are made on significant trends and problems.

\section{INTRODUCTION}

To the TRANSIENT visitor, Te Kuiti conjures up a mixture of - glow-worm grottos, noisy night trains, men's clubs and Colin Meads. But the backbone of the district is its farming. This paper describes the local farming pattern, and comments are made on progress, problems and trends.

\section{DISTRICT DEFINITION}

The Te Kuiti district is interpreted as being Waitomo County, the central of the three counties which comprise the King Country. To the north lies Otordhanga County where dairying is the main type of farming praotised. To the south Taumarunui is the core of an expansive stretch of sheep and beef cattle farming.

Waitomo County itself comprises 336000 ha, 'about the same size as Waimate County in the South Island. Three-quarters of the area is occupied by 750 farm holdings. Average farm size is 334 ha. The county is almost entirely concerned with growing meat and wool. Only $6 \%$ of farms derive most of their income from dairy produce, and these are nearly all located on the northern fringe adjoining Otorohanga.

\section{CLIMATE}

Te Kuiti's annual average rainfall is $1450 \mathrm{~mm}$, falling on 170 rain days. But throughout the district the rainfall ranges from 1100 to $3000 \mathrm{~mm}$ in the western bills. In most years rainfall is well distributed but recently, beginning with the 1969:70 drought, summer/autumn deficits have occurred. Annual average sunshine hours are 1800 . Frosts are a feature of the winter months, and they can be 'severe in sheltered valleys. Te Kuiti records 40 to 50 frosts a year and Pureora Forest 'averages 85 . Summers are mild and temperatures on several days during 
T E KUITI DISTRICT FARMING . •

January and February exceed $26^{\circ} \mathrm{C}$. Apart from the exposed west coast, the district is generally free from strong winds.

\section{TOPOGRAPHY}

Parallel with the west coast runs a backbone Of moderate to steep hill country rising to $790 \mathrm{~m}$ above sea-level. Slung within a horse-shoe formed by this western range, the Rangitoto. Range in the east, and a hilly chain 'bordering Taumarunui County, lies an expanse of easy hill country tilting northwards. The loftiest point is Mt Pureora in the south-eastern corner, with a height of $1165 \mathrm{~m}$.

\section{$S O \perp L S$}

District soils are grouped into three main types. Forty per cent of the area is coated in Mairoa ash. Another $40 \%$, including the steeper country, belongs to the Mahoenui hill soils, land Taupo ash covers the balance.

\section{LAND DEVELOPMENT}

The tree-dotted countryside. we see today reminds us of the original cover of broadleaf-podocarp bush, mainly tawa, matai, rimu and taraire. Following close on the heels of King Tawhiao's protest to Queen Victoria over the pakeha opening up land, Waitomo's first European settlement took place at Mokau in 1893. The ensuing eighty years of bushland development marks an outstanding chapter in the history of New Zealand agriculture.

Development in the early days was haphazard - roaring bushfires in an unroaded wilderness. Completion of the Main Trunk Railway in 1908 'sparked off a timber boom, and the associated roading and tracking led to more orderly land clearing. The bulldozer, the discovery of cobalt as a cure for bush sickness, and aerial topdressing were each a catalyst for land development.

In the 1930s the Government recognized the importance of land development in the King Country by establishing a Land Development branch of the Lands and Survey Department in Te Kuiti. At present this branch. directs operations on 59000 ha ranging from Coromandel Peninsula to National Park.

In the early days development consisted of felling the smaller trees left over from milling, and sowing seed on the ash left from burns. Today the method is little different even when the bulldozer is used. Only the smaller trees are pushed over, the bigger trees being bypassed to save costs. Where the contour. is too steep for the bulldozer, the land is of ten better left untouched. 
A few years-after burning, a. programme of stumpitig, "cropping and regrassing was followed on the easy country. On. the steeper bill country, initial establishment of pasture was good, but low natural soil fertility led to a reversion to scrub and fem. This process was often repeated two or three times before control was achieved.

Even in more recent years, when the technical know-how was available, some development programmes failed. through lack-. of foresight and planning. The temptation to a match-happy owner to, burn off often resulted in too large an 'area being tackled for the resources available. For a development programme to succeed, it must allow not only for initial clearing and seed-sowing, but also for capital topdressing, fencing and stocking.

Figure 1 illustrates recent grassland development trends..

r. -Between 1961-2 and 197 1.2 'the area in grass increased 15\%. Over the 4 -year period 'to 1965-6 fertilizer usage rose. 55\% but a setback followed the 1966 drop in the wool price.

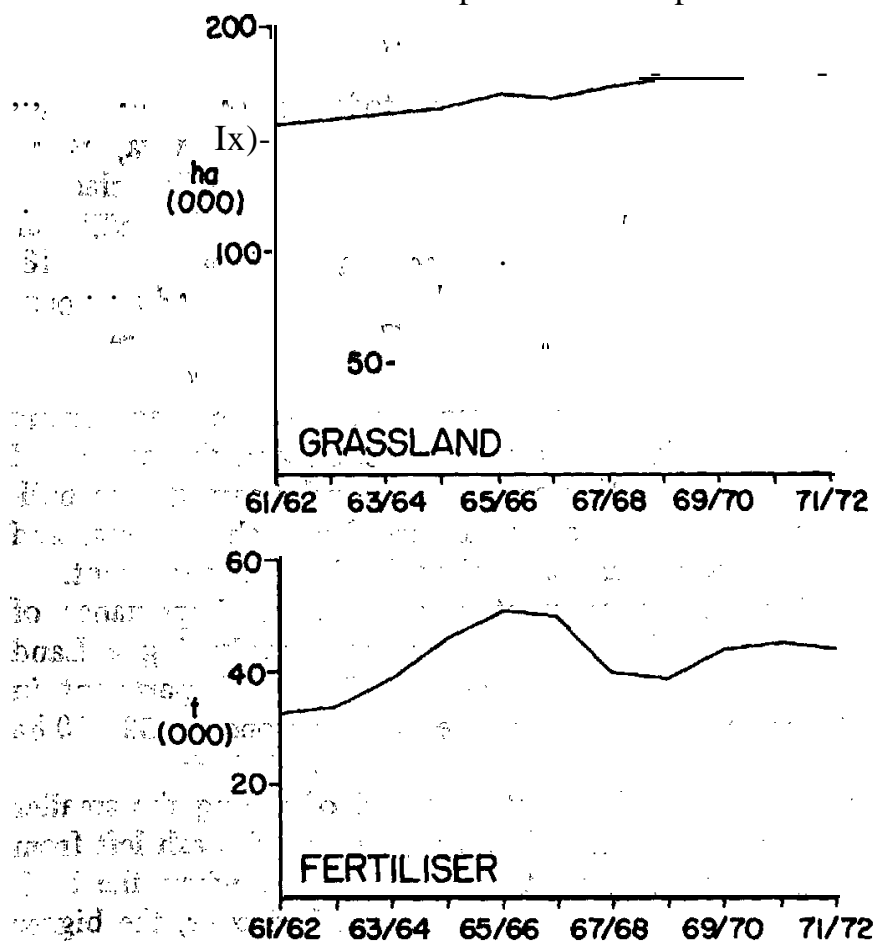

Fic. 1: Area of grassland and quantity of fertilizer used from 1961-2 to Mak 1971-2, Waitomo County. 
The State Advances Corporation has played a dominant role in lending for development and purchase.

\section{PASTURE SEEDS MIXTURES}

Commonly, the seeding rate of aerially-sown pastures is about $30 \mathrm{~kg} / \mathrm{ha}$, comprising $24 \mathrm{~kg}$ of grasses and $6 \mathrm{~kg}$ of clovers. Lower rates are used on cultivated ground.

Ryegrasses constitute $80 \%$ of the grass component. 'Grasslands Ruanui' perennial ryegrass is the main ingredient for low-fertility soils. The higher the soil fertility, the greater the role 'Grasslands Ariki' ryegrass will play. 'Grasslands Manawa' short-rotation ryegrass is sometimes used as a filler, 'Grasslands Apanui' cocksfoot establishes well under rotational grazing, and crested dogstail withstands close grazing by sheep.

'Grasslands Huia' white clover is the basic clover species sown, although 'Grasslands Hamua' broad red clover may be added, and subterranean clover is useful on sunny faces. Inoculation of the clover seed is recommended for sowing virgin country and for oversowing.

\section{TOPDRESSIN G}

For most sheep farmers, normal practice is to topdress with $250 \mathrm{~kg} / \mathrm{ha}$ of straight super-phosphate each year although soil tests are revealing a potassium deficiency in soils supporting longestablished pastures. Hay paddocks are often blessed with an extra 250 to $375 \mathrm{~kg} / \mathrm{ha}$ of potassic superphosphate. Intensively grazed units may recei ve up to $750 \mathrm{~kg}$ annually.

In development programmes where farmers are dealing with low soil levels of available phosphorus $1250 \mathrm{~kg} / \mathrm{ha}$ superphosphate are usually recommended in the first year.

\section{-LIVESTOCK}

Over the decade 1957 to 1967 sheep and beef cattle numbers rose sharply, as shown in Fig. 2. On a stock-unit basis, the increase was $64 \%$.

Drier seasons and the low wool price exerted a steadying effect over the next 5 years. But a direct comparison of 1972 data with earlier figures is not valid because:

(a) Colleotion of cattle data switched from January to June in 1971.

(b) The 1972 Sheep Retention Scheme discovered many "lost" sheep. 
SHEEP $(000)$

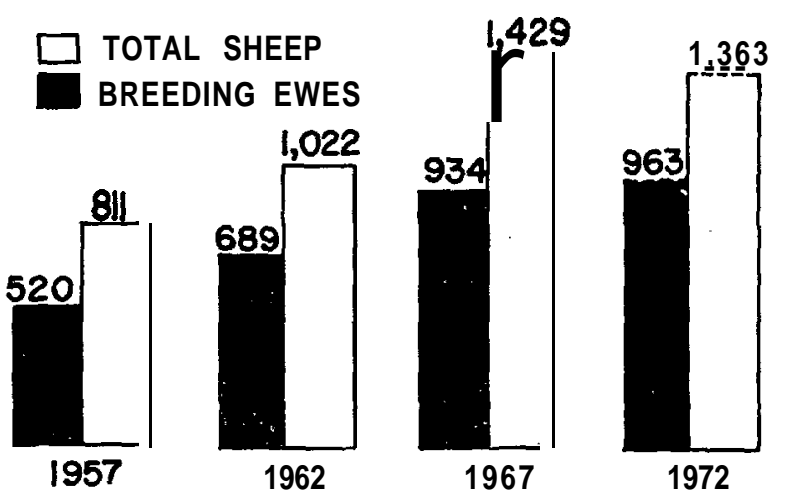

\section{BEEF CATTLE (으)}
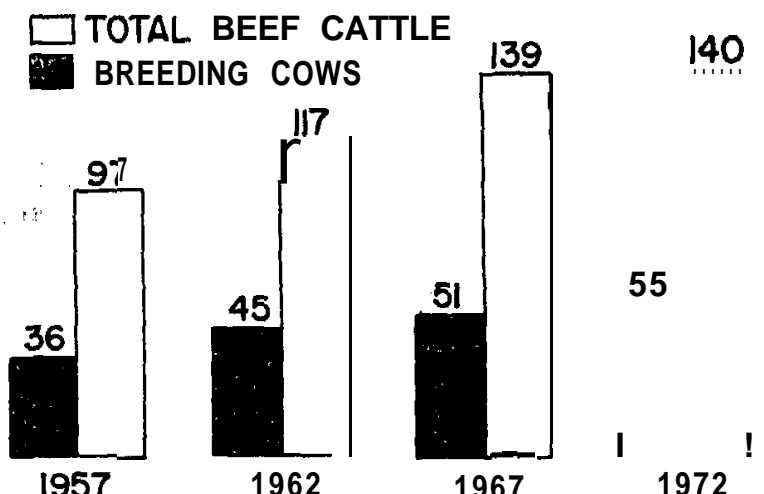

55

FIG. 2: Numbers of sheep and beef cattle in 1957, 1962, 1967, and 1972, Waifomo County.

According to the Department of Statistics, the County wintered 1363000 sheep, 140000 beef cattle and 12000 dairy cattle in 1972. Tbis represents 11 stock-u\&s/ha grazed. But as the stockunit system is based on a $54 \mathrm{~kg}$ ewe and $100 \%$ lambing, this average stocking rate is artificially inflated. Waitomo sheep average only $92 \%$ lambing and 45 to $50 \mathrm{~kg}$ liveweight. Calving performance seldom betters 80 to $85 \%$.

On the steeper hill country, the policy with both sheep and cattle is to breed replacements and sell surplus stock as young 
stores. On the better hill country this system is modified by fattening a proportion of the lambs and carrying weaner steers through to 18 months. On the best country, mixed-aged ewes are bought in and run with a fat lamb sire, the progeny being sold fat. Weaner or 18-month-old steers are also bought in for fattening.

The Romney remains on its pedestal as the dominant sheep breed, but on the steeper country the Perendale is increasing, and on the easy country Coopworths are appearing. The Angus still reigns supreme amongst the beef breeds, although the Hereford has its advocates and first-cross heifers of the two are in demand. Friesian blood, unseen in the district five years ago, is starting to invade the traditional beef domain.

\section{SIGNIFICANT MANAGEMENT TRENDS}

The price plummet for wool and sheep-meats over the period 1966-7 1, coupled with the effects of the 1969-70 drought and subsequent dry summers, profoundly influenced farm management. A number of young farmers, having acquired their properties in the early 1960s were placed in shaky financial positions. The hill country farmer did not have the scope for diversification. Because of this, and goaded by extension effort, a greater awareness of the business side of farming is becoming apparent. More farmers are now analysing their livestock policies and performances, budgeting, and using accounting services.

On-farm recording of livestock performance is a worthy innovation. Weaners fetching over $\$ 100$ in the autumn fairs, and the beef schedule rising above $\$ 30$ per $0.45 \mathrm{~kg}$, highlight the value of a $\$ 300$ outlay on a set of scales since 'superior animals can be more easily identified. Because lambing percentages are known to benefit, farmers are making an effort to lift ewe liveweights over tupping. Stock performance now has priority over stocking rate.

Planned feeding, particularly over winter, is another notable development. Sheep farmers have always lagged behind dairy farmers in manipulating feed supplies to fit stock needs. For years breeding cows were banished to the outback to fend for themselves. Feed dwindled as their needs rose approaching calving. But a $\$ 150$ beast deserved better treatment. Rationed feeding of saved grass in late winter, involving paddock, block or strip-grazing is now the rule, not the exception, for breeding cows, and for weaners. Extension of the rotational system to 


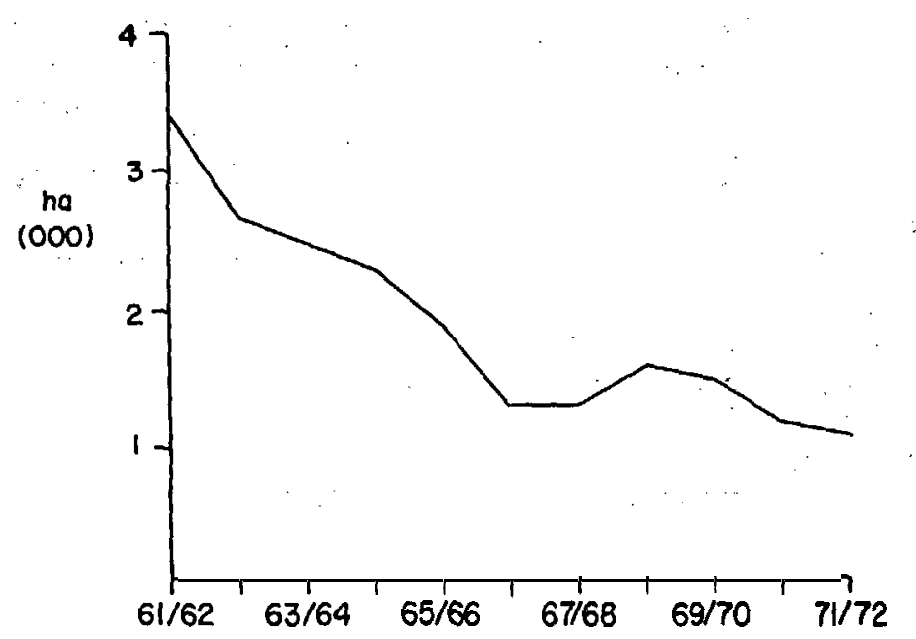

Fig. 3: Area in winter crops from 1961-2 to 1971-2, Waitomo County.

sheep is normal practice from weaning to lambing. But sheep farmers have more classes of stock to manage than dairy farmers, and so the number of paddocks, contour, and labour can limit the adoption of rotational grazing for all classes of stock.

Emphasis on grass wintering has lessened the need for cropping. Only where crops are associated with development programmes can they be justified on economic grounds. The trend away from cropping is illustrated in Fig. 3.

The use of' nitrogen to boost winter and early spring pasture growth is increasing, and is the subject of a separate paper. Farmers are more conscious of soil types and their respective fertilizer requirements. The impact of the Te Kuiti Field Research Area, low prices for sheep products up to 1971 , and the reduction of fertilizer subsidies have led to this greater awareness .

Establishment of an intensive grazing unit within a property is an interesting district development. The N.Z. Pastoral Holdings' Beef Demo\&ration Unit, which operated for three years, promoted the idea. A portion of the farm, usually easy country having potential, is selected for preferential topdressing and subdivision. Upgrading such an area enables different classes of stock to be intensively managed at critical times. Some farmers use their unit solely for finishing beef. But possible uses are wide - it could be used to run breeding cows and calves to improve weaner 
liveweight, it could eaable replacement heifers to reach suitable liveweights to calve down as two-year-olds instead of three-yearolds, it could fatten lambs, it could lift hogget or ewe liveweight for tupping. Intensive units help reduce the traditional gap between winter and summer. carrying capacities. Additional areas can be incorporated into the system in later years. Pasture improvement, under this concentrated rotational grazing, .. can be dramatic.

\section{RESEARCH}

The focal point of research in the district is the Te Kuiti Field Research Area, $19 \mathrm{~km}$ south of the borough. The district is also serviced by a field research team based at Ruakura. Current farm trials include the investigation of lime on Mairoa ash and the frequency of worm drenching of lambs.
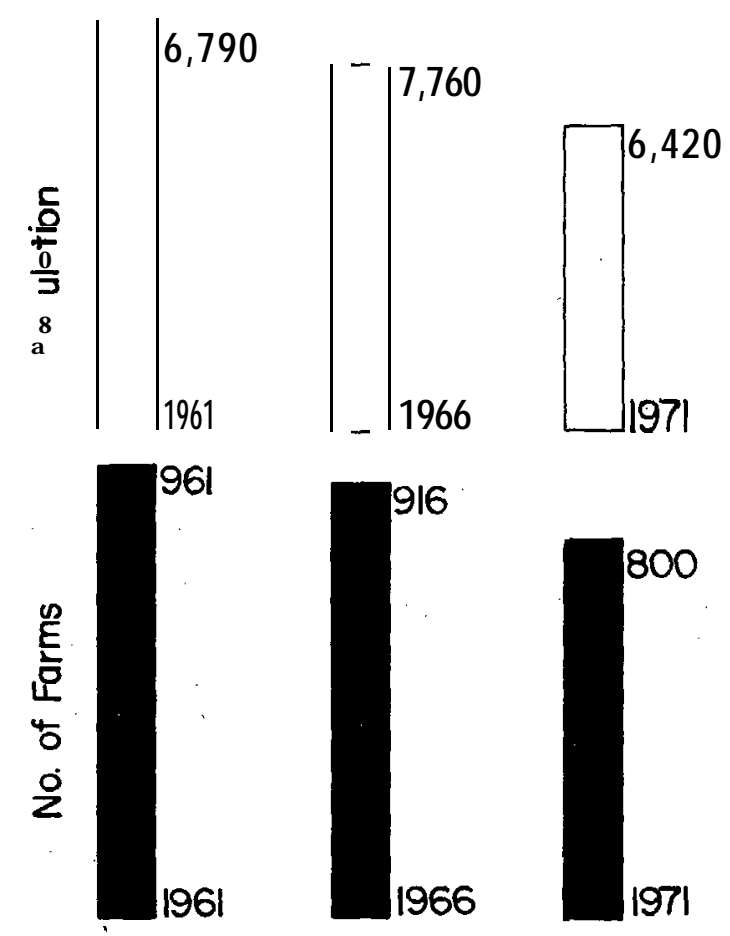

FIG. 4: Population and number of farms in 1961, 1966, and 1971, Waitomo County. 


\section{AMENITIES}

Te Kuiti (population 4842 in 1971) and Piopio are the main servicing centres. Throughput for the 1972-3 season for their saleyards amounted to 350000 stock units, $18 \%$ of the total wintered in 1972. Many outside buyers are attracted, mainly from the Waikato, although increasing numbers of stock are retained within the district for finishing.

Owing to its inland position away from the large centres, the district suffers in peak periods from delays in the delivery of stock to the freezing works, and of fertilizer. Freezing works are located at Waitara, Westfield and Horotiu and fertilizer supplies come from New Plymouth, Auckland and Mt Maunganui.

\section{PROBLEMS}

Hill-country farming faces three main problem areas: declining social services, shortage of trained labour, and inadequate research effort.

Both numbers of people and of farms have fallen in Waitomo Country as illustrated in Fig. 4.

Closure of schools and stores, and a reduction in public transport and rural freight services have accompanied the trend. Should services in areas of scattered population be expected to pay their own way?

A shortage of trained labour often induces labour-saving shortcuts not always in the best interests of sound farm management.

The scope for more researoh is wide. For instance, we do not know how much dry matter our hill country pastures produce. No reliable measuring technique has yet been devised although some data have been obtained, as will be shown in a later paper. Clovers tend not to persist in pastures. Although grazing management has a marked influence on clover content, the problem needs investigating. Some other fields warranting research effort are ewe liveweight, the effect on lambing percentage of liveweight losses after tupping, phosphorus maintenance of bill soils, the effect of lime on animal production, and chemical control of manuka.

\section{CONCLUSION}

Farming in the Te Kuiti district expanded remarkably during the 1960s. Continuation of fair prices for produce, the application of proven farm management teohniques, and Government sympathy in problem fields would cement the district's position as a significant contributor to. the well-being of New Zealand: 